\title{
PENGARUH SISTEM OLAH TANAH DAN RESIDU PEMUPUKAN N JANGKA PANJANG TERHADAP KADAR N TOTAL TANAH, SERAPAN N DAN PRODUKSI KACANG TUNGGAK (Vigna unguiculata L.)
}

\section{THE EFFECT OF LONG-TERM TILLAGE SYSTEM AND N FERTILIZER RESIDUE ON TOTAL SOIL N, N UPTAKE AND YIELD OF COWPEA (Vigna Unguiculata L.)}

\author{
Mislan Agustin', Supriatin Supriatin ${ }^{2 *}$, Muhajir Utomo dan Sarno $^{2}$ \\ ${ }^{1}$ Program Studi Agroteknologi, Fakultas Pertanian, Universitas Lampung, Bandar Lampung, Indonesia \\ ${ }^{2}$ Program Studi Ilmu Tanah, Fakultas Pertanian, Universitas Lampung, Bandar Lampung, Indonesia \\ *Email: supriatin.1979@fp.unila.ac.id \\ * Corresponding Author, Diterima: 21 Des. 2020, Direvisi: 26 Mar. 2021, Disetujui: 7 Apr. 2021
}

\begin{abstract}
Cowpea (Vigna unguiculata L.) is a legume that has root nodules, which can fix up $\mathrm{N}_{2}$ gas from the atmosphere. The presence of nitrogen in soil derived from fertilizer will affect the total $N$ content of the soil and the amount of $N$ taken up by the legume. This study aimed to determine the effect of soil tillage system and nitrogen fertilizer residue on total $N$ levels of soil, $N$ uptake and yield of cowpea. The study was conducted in April to July 2019 on the experimental fields of Lampung Polytechnic, using a Randomized Block Design (RDB) arranged in two treatment factors. The first factor was the long-term tillage system, i.e. $T 0=$ no tillage, $T 1=$ minimum tillage, $T 2=$ intensive tillage. The second factor was the longterm nitrogen fertilizer residue, i.e. $N 0=$ control and $N 2=$ residue of $200 \mathrm{~kg} \mathrm{~N} \mathrm{ha}^{-1}$. The data obtained were tested for homogeneity by Bartlett's test, data additivity were tested by the Tukey's test. The data were furthet analyzed using Analysis of Variance and continued with Least Significance Difference (LSD) test at 5\% significance level. The results showed that the tillage system did not affect the total $N$ content of the soil, but the tillage system showed a very significant effect on shoot $N$ uptake and total $N$ uptake of cowpea plants. The $N$ uptake of cowpea shoots in the intensive tillage system was higher than that with no tillage, but it was not significantly different from that of the minimum tillage. While the total $N$ uptake of plants in the minimum tillage treatment was higher than that of intensive tillage, but it was not significantly different from that with no tillage. Nitrogen fertilization residue did not affect total $N$ levels of soil and $N$ uptake by the cowpea shoots. There was an interaction effect between soil tillage system and $N$ fertilizer residue on the yield of cowpea. The highest yield was obtained in the minimum tillage system

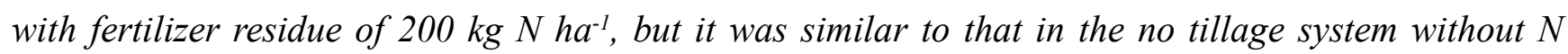
fertilizer residue and with residue $200 \mathrm{~kg} \mathrm{~N} \mathrm{ha}^{-1}$.
\end{abstract}

Keywords: Cowpea, nitrogen, uptake, tillage, fertilizer residue.

\begin{abstract}
ABSTRAK
Tanaman kacang tunggak (Vigna unguiculata L.) merupakan tanaman leguminosa yang memiliki bintil akar untuk menambat $\mathrm{N}$ dari udara. Adanya nitrogen di dalam tanah akan mempengaruhi kadar $\mathrm{N}$ total tanah dan
\end{abstract}


serapan N. Penelitian ini bertujuan untuk mengetahui pengaruh sistem olah tanah dan residu pemupukan nitrogen jangka panjang terhadap serapan $\mathrm{N}$, kadar $\mathrm{N}$ total tanah dan produksi tanaman kacang tunggak. Penelitian ini dilaksanakan pada April sampai Juli 2019 di lahan Politeknik Negeri Lampung Bandar Lampung, menggunakan Rancangan Acak Kelompok (RAK) yang disusun secara faktorial dengan dua faktor perlakuan. Faktor pertama yaitu residu pemupukan nitrogen jangka panjang yang terdiri dari $\mathrm{N}_{0}=$ kontrol dan $\mathrm{N}_{2}=200 \mathrm{~kg} \mathrm{~N} \mathrm{ha}^{-1}$. Faktor kedua yaitu sistem olah tanah yang terdiri dari $\mathrm{T}_{0}=$ tanpa olah tanah, $\mathrm{T}_{1}=$ olah tanah minimum, $\mathrm{T}_{2}=$ olah $\operatorname{tanah}$ intensif. Data yang diperoleh diuji homogenitas ragamnya dengan Uji Bartlett dan aditivitas data diuji dengan Uji Tukey. Data dianalisis ragam dan dilanjutkan dengan uji BNT pada taraf nyata $5 \%$. Hasil penelitian menunjukkan bahwa sistem olah tanah tidak mempengaruhi kadar $\mathrm{N}$ total tanah, namun sisremoleh tanah berpengaruh sangat nyata terhadap serapan $\mathrm{N}$ brangkasan dan total serapan $\mathrm{N}$ pada tanaman kacang tunggak. Serapan $\mathrm{N}$ brangkasan tanaman kacang tunggak pada perlakuan sistem olah tanah intensif lebih tinggi dibandingkan dengan tanpa olah tanah, namun tidak berbeda nyata dengan olah tanah minimum. Sedangkan total serapan N pada tanaman kacang tunggak pada perlakuan olah tanah minimum lebih tinggi dibandingkan dengan olah tanah intensifnamun tidak berbeda nyata dengan tanpa olah tanah. Residu residu pemupukan nitrogen tidak mempengaruhi kadar $\mathrm{N}$ total tanah dan serapan $\mathrm{N}$ pada tanaman kacang tunggak. Terdapat pengaruh interaksi antara sistem olah tanah dan residu pemupukan nitrogen terhadap produksi tanaman kacang tunggak. Produksi tanaman kacang tunggak tertinggi terdapat pada interaksi perlakuan sistem olah tanah minimum dengan residu pemupukan $200 \mathrm{~kg} \mathrm{Nha}^{-1}$, namun tidak berbeda nyata dengan perlakuan tanpa olah tanah dengan kontrol dan residu pemupukan $200 \mathrm{~kg} \mathrm{Nha}^{-1}$.

Kata kunci : Kacang tunggak, nitrogen, sistem olah tanah, serapan, residu pupuk.

\section{PENDAHULUAN}

Kacang tunggak (Vigna unguiculata L.) telah lama dibudidayakan di Indonesia. Kacang tunggak biasanya ditanam petani dalam skala kecil secara monokultur atau tumpangsari dengan jagung, ubi kayu, cabe atau kapas sebagai sumber bahan pangan. Secara alamiah kacang tunggak tergolong tanaman kacangkacangan yang toleran terhadap kekeringan. Seperti halnya pada tanaman kacang-kacangan yang lain, waktu tanam merupakan faktor penting yang menentukan tingkat keberhasilan budidaya kacang tunggak untuk mencapai tingkat produktivitas yang tinggi. Pada lahan sawah yang memiliki fasilitas irigasi teknis, kacang tunggak ditanam sesudah padi pada bulan Juni/Juli, sedangkan pada lahan sawah irigasi terbatas, ditanam pada bulan Maret/April. Pada lahan kering setelah jagung, kacang tunggak ditanam pada bulan Februari/Maret dan sedikit sekali kacang tunggak ditanam pada awal musim hujan (November/ Desember) (Adisarwanto dkk., 1998).

Sumber daya genetik kacang tunggak yang ada memiliki keragaman untuk hasil dan sifat lain seperti warna biji, ukuran biji, serta umur masak. Potensi hasil kacang tunggak berkisar 1,0 hingga 2,0 ton ha ${ }^{-1}$ biji kering, tergantung varietas, lokasi, musim, dan cara budidaya (Trustinah, 1998). Kacang tunggak memiliki beberapa varietas yang dibudidaya di Indonesia seperti varietas Nagara yang memiliki potensi hasil berkisar antara $0,4-0,5$ ton ha $^{-1}$ dan varietas lokal yang memiliki potensi hasil antara 1,5-1,8 ton ha' ${ }^{-1}$.

Masalah utama yang dihadapi dalam pengembangan usaha tani kacang tunggak adalah sebagai berikut: 1) belum adanya teknologi budidaya yang sesuai dengan kemampuan petani, 2) hambatan 
sosial, misalnya kebiasaan dan kurangnya informasi tentang kacang tunggak, 3) belum tersedianya pasar baik pasar lokal maupun pasar ekspor, 4) belum berkembangnya industri pertanian yang mengutamakan bahan baku kacang tunggak. Selain itu, penyebab rendahnya produksi kacang tunggak karena rendahnya kandungan unsur hara di dalam tanah akibat hilangnya unsur hara melalui penguapan dan pencucian. Sedangkan perkembangan tanaman yang sehat dicerminkan oleh status hara yang optimal, konsentrasi hara, serta besarnya serapan N, P dan K dalam jaringan tanaman (Aqil dan Rahmi, 2013).

Untuk meningkatkan produktivitas kacang tunggak diperlukan teknik budidaya yang tepat, salah satunya adalah dengan pengolahan tanah. Untuk mempertahankan kualitas tanah agar tetap baik, dapat dilakukan dengan menggunakan prinsip olah tanah konservasi (OTK). Sistem olah tanah konservasi terdiri dari tanpa olah tanah (TOT) dan olah tanah minimum (OTM). Olah tanah konservasi dalam cara penyiapan lahan dapat mengurangi erosi, menyimpan karbon tanah, meningkatkan biodiversitas tanah, mendaur-ulang hara internal, memantapkan agregasi tanah dan meningkatkan konservasi air (Utomo, 2015).

Aplikasi pupuk baik pupuk organik maupun anorganik pada pertanaman sebelumnya akan meninggalkan residu di dalam tanah yang dapat dimanfaatkan oleh tanaman pada pertanaman berikutnya. Menurut Hartatik dan Widowati (2006), adanya residu pupuk organik yang diberikan saat musim tanam I dapat meningkatkan ketersediaan hara bagi tanaman pada musim tanam selanjutnya, sehingga respon tanaman yang dihasilkan juga lebih baik. Secara umum tanaman kacang-kacangan cukup menggunakan $\mathrm{N}$ yang berasal dari residu pada pertanaman sebelumnya karena tanaman kacang-kacangan mampu mengikat nitrogen dari udara untuk meningkatkan produktivitas tanaman. Berkaitan dengan hal-hal tersebut, perlu dilakukan penelitian untuk mengetahui pengaruh sistem olah tanah dan pemupukan $\mathrm{N}$ jangka panjang terhadap kadar $\mathrm{N}$ total tanah, serapan $\mathrm{N}$ serta produksi kacang tunggak pada tanah masam Ultisol.

Penelitian ini bertujuan untuk (1) mengetahui pengaruh sistem olah tanah terhadap kadar $\mathrm{N}$ total tanah, serapan $\mathrm{N}$ dan produksi kacang tunggak, (2) mengetahui pengaruh residu pemupukan $\mathrm{N}$ terhadap kadar $\mathrm{N}$ total tanah, serapan $\mathrm{N}$ dan produksi kacang tunggak, (3)mengetahui pengaruh interaksi antara sistem olah tanah dan residu pemupukan $\mathrm{N}$ terhadap kadar $\mathrm{N}$ total tanah, serapan $\mathrm{N}$ dan produksi kacang tunggak.

\section{BAHAN DAN METODE}

Penelitian ini dilaksanakan pada bulan April sampai Juli 2019 di lahan kampus Politeknik Negeri Lampung dan Laboratorium Ilmu Tanah, Fakultas Pertanian Universitas Lampung. Bahan-bahan yang digunakan dalam penelitian ini adalah benih kacang tunggak varietas Gayabaru, SP-36, KCl, Roundup (Glifosfat), Lindomin 865 SL(Dimetil Amina) dan bahan lain yang digunakan untuk keperluan analisis sampel tanah dan tanaman di laboratorium. Alat-alat yang digunakan adalah bor ulir, gunting, pisau, cangkul dan alat yang digunakan pada analisis laboratorium berupa oven, timbangan, dan labu destilasi. Penelitian ini dilakukan dengan menggunakan Rancangan Acak Kelompok (RAK) yang disusun secara faktorial dengan 
4 ulangan. Faktor pertama adalah sistem olah tanah jangka panjang yaitu $\mathrm{T}_{0}=$ Tanpa Olah Tanah $(\mathrm{TOT})$, $\mathrm{T}_{1}=$ Olah Tanah Minimum (OTM), $\mathrm{T}_{2}=$ Olah Tanah Intensif (OTI) dan faktor kedua adalah residu pemupukan $\mathrm{N}$ jangka panjang yaitu $\mathrm{N}_{0}=$ Kontrol dan $\mathrm{N}_{2}=200 \mathrm{~kg} \mathrm{~N} \mathrm{ha}^{-1}$. Jumlah petak perlakuan dalam penelitian ini adalah 24 petak percobaan.

Penelitian ini merupakan penelitian jangka panjang yang telah berjalan selama 32 tahun. Pada tahun ke-32 musim pertama ditanami jagung, kemudian lahan dibersihkan dan dibagi menjadi 24 petak dengan luas masing-masing petak $4 \mathrm{~m} \times 6 \mathrm{~m}$. Pada saat 2 minggu sebelum penanaman kacang tunggak, lahan disemprot menggunakan herbisida Lindomin 865 SL dengan dosis $2 \mathrm{~L} \mathrm{ha}^{-1}$ untuk gulma berdaun lebar dan Roundup dengan dosis $3 \mathrm{~L} \mathrm{ha}^{-1}$ untuk gulma berdaun sempit atau teki, kemudian gulma yang sudah mati digunakan sebagai mulsa pada petak perlakuan tanpa olah tanah (TOT) ditambah dengan sisa-sisa tanaman jagung. Sedangkan pada petak olah tanah minimum (OTM) tanah dicangkul dangkal dan gulma digunakan sebagai mulsa, dan pada olah tanah intensif (OTI) tanah dicangkul dua kali hingga kedalaman $20 \mathrm{~cm}$ dan sisa tanaman gulma dibersihkan dari petak percobaan.

Variabel utama yang diukur dalam penelitian ini, yaitu kandungan $\mathrm{N}$ total tanah (metode Kjeldahl), serapan $\mathrm{N}$ jaringan tanaman (metode Kjeldahl) dan produksi tanaman kacang tunggak. Sedangkan variabel pendukung yang diukur yaitu $\mathrm{pH}$ tanah (metode elektrode gelas) dan kandungan C-organik di dalam tanah (metode Walkey dan Black) (Thom dan Utomo, 1991). Homogenitas ragam dari masing-masing variabel utama dan pendukung diuji dengan uji Bartlett dan aditivitas data diuji dengan uji Tukey. Jika asumsi terpenuhi, data akan dianalisis dengan Analisis Ragam. Jika pengaruh masing-masing perlakuan terhadap variabel utama dan pendukung nyata maka perbedaan nilai rata-rata dari variabel utama dan pendukung pada masing-masing perlakuan akan diuji dengan uji Beda Nyata Terkecil(BNT)pada taraf nyata 5\%(Susilo, 2013).

Sampel tanah awal diambil satu minggu sebelum panen tanaman jagung pada musim ke-32 periode 1 atau sekitar 3 bulan sebelum pengambilan sampel tanah akhir. Kemudian sampel tanah akhir diambil satu minggu sebelum panen tanaman kacang tunggak pada periode tanam ke-2 (penelitian ini). Sampel tanah diambil dengan menggunakan bor tanah pada kedalaman 0-20 cm secara komposit sebanyak 3 titik per petak percobaan. Kemudian, sampel tanah dikompositkan per petak percobaan. Sampel tanah yang telah dikompositkan lalu dikering-anginkan, dihaluskan dan disaring dengan menggunakan ayakan $2 \mathrm{~mm}$. Setelah itu, sampel tanah siap dianalisis kandungan $\mathrm{N}$-total, C-organik dan $\mathrm{pH}$.

Jumlah sampel tanaman yang diambil per plot percobaan sebanyak 10 tanaman. Pengambilan sampel brangkasan tanaman dilakukan dengan memotong bagian tajuk tanaman dengan menggunakan gunting lalu dimasukkan ke dalam amplop coklat. Brangkasan tanaman dan polong masing-masing ditimbang untuk mengetahui bobot basahnya kemudian dilakukan pengovenan selama $3 \times 24$ jam pada suhu $70^{\circ} \mathrm{C}$. Setelah dioven brangkasan dan polong ditimbang untuk mengetahui bobot kering brangkasan dan bobot kering polong, lalu brangkasan dan polong digiling untuk digunakan sebagai sampel analisis serapan $\mathrm{N}$ pada 
tanaman. Kandungan N-total (metode Kjeldahl) dianalisis pada sampel jaringan tanaman (brangkasan dan polong). Untuk mengetahui jumlah unsur hara $\mathrm{N}$ yang terangkut oleh tanaman dilakukan perhitungan serapan $\mathrm{N}=$ Kadar $\mathrm{N}$ di dalam jaringan tanaman (brangkasan atau polong) (\%) x Bobot kering brangkasan atau polong $\left(\mathrm{kg} \mathrm{ha}^{-1}\right)$ (Thom dan Utomo, 1991). Produksi kacang tunggak ditentukan dengan menimbang bobot biji dan mengukur kadar air di lapang kemudian dikonversi menjadi 12\%. Bobot biji (Mg $\mathrm{ha}^{-1}$ ) adalah hasil konversi dari petak panen dengan ukuran $1 \mathrm{~m}$ x $1 \mathrm{~m}$.

\section{HASIL DAN PEMBAHASAN}

\section{Kadar N Total Tanah Awal dan Akhir}

Hasil penelitian (Tabel 1) menunjukkan bahwa perlakuan residu pemupukan $\mathrm{N}$ dan sistem olah tanah serta interaksi keduanya tidak memberikan pengaruh nyata terhadap kadar $\mathrm{N}$ total tanah awal dan akhir. Residu $\mathrm{N}$ total tanah yang berasal dari pertanaman sebelumnya ( $\mathrm{N}$ total tanah awal) dan residu $\mathrm{N}$ total tanah akhir setelah pertanaman kacang tunggak tergolong rendah dengan kandungan $\mathrm{N}$ total $0,08 \%$ 0,21\% (Eviati dan Sulaeman, 2009). Hal tersebut diduga karena tanah tidak diberi pupuk nitrogen dan hanya memanfaakan residu $\mathrm{N}$ tanaman sebelumnya serta rendahnya C-organik tanah (Tabel 3) yang menyebabkan rendahnya N-total tanah. Menurut Hanafiah (2013) unsur N di dalam tanah berasal dari hasil dekomposisi bahan organik sisa-sia tanaman maupun hewan dan pemupukan (terutama urea dan ammonium nitrat). Tidak adanya pengaruh residu pemupukan $\mathrm{N}$ terhadap kadar $\mathrm{N}$ total tanah awal dan akhir diduga karena sifat $\mathrm{N}$ yang labil dan mudah tercuci sehingga pada perlakukan residu pupuk $\mathrm{N}$ tidak berpengaruh terhadap N-total tanah. Sistem olah tanah

Tabel 1. Pengaruh residu pemupukan $\mathrm{N}$ dan sistem olah tanah terhadap kadar $\mathrm{N}$ total tanah awal dan akhir pada pertanaman kacang tunggak.

\begin{tabular}{ccc}
\hline \multirow{2}{*}{ Perlakuan } & Kadar N total tanah awal & Kadar N total tanah akhir \\
\cline { 2 - 3 } & $(\%)$ & $(\%)$ \\
N0T0 & 0,16 & 0,12 \\
N0T1 & 0,10 & 0,13 \\
N2T0 & 0,08 & 0,10 \\
N2T1 & 0,12 & 0,12 \\
N2T2 & 0,21 & 0,12 \\
\end{tabular}

Keterangan : $\mathrm{N}_{0}=$ Kontrol; $\mathrm{N}_{2}=$ Residu Pupuk N $200 \mathrm{~kg} \mathrm{ha}^{-1} ; \mathrm{T}_{0}=$ Tanpa Olah Tanah; $\mathrm{T}_{1}=$ Olah Tanah Minimum; $\mathrm{T}_{2}=$ Olah Tanah Intensif.

Tabel 2. Pengaruh residu pemupukan $\mathrm{N}$ terhadap $\mathrm{pH}$ tanah awal dan akhir pada pertanaman kacang tunggak.

\begin{tabular}{ccc}
\hline Perlakuan & $\mathrm{pH}$ tanah awal & $\mathrm{pH}$ tanah akhir \\
\hline N0 & $6,65 \mathrm{a}$ & $6,04 \mathrm{a}$ \\
N2 & $6,17 \mathrm{a}$ & $5,69 \mathrm{~b}$ \\
\hline BNT 5\% & 0,6 & 0,12 \\
\hline
\end{tabular}

Keterangan : Angka yang diikuti oleh huruf yang sama tidak berbeda nyata menurut uji BNT 5\%. $\mathrm{N}_{0}=\mathrm{Kontrol}_{2} \mathrm{~N}_{2}=$ Residu Pupuk N 200 kg ha-1. 
tidak memberikan pengaruh nyata terhadap kadar $\mathrm{N}$ total tanah. Hal tersebut diduga karena pada perlakuan olah tanah minimum dan tanpa olah tanah di tahun ke32 tanah sudah mulai mengalami pemadatan (kekerasan) yang mengakibatkan aerasi tanah menjadi kurang baik, sehingga proses dekomposisi bahan organik tidak optimal khususnya pada sistem tanpa olah tanah dan olah tanah minimum, sedangkan sistem olah tanah intensif memberikan keadaan gembur agar perakaran tanaman dapat berkembang baik (Utomo, 2012).

\section{pH Tanah Awal dan Akhir}

Hasil analisis ragam menunjukkan bahwa perlakuan residu pemupukan $\mathrm{N}$ berpengaruh sangat nyata terhadap $\mathrm{pH}$ tanah awal dan akhir, tetapi sistem olah tanah tidak berpengaruh terhadap $\mathrm{pH}$ tanah awal dan akhir. Selain itu, tidak terdapat pengaruh interaksi antara sistem olah tanah dan residu pemupukan $\mathrm{N}$ terhadap pH tanah awal maupun akhir. Hasil uji BNT (Tabel 2) menunjukkan bahwa pH tanah awal dan akhir pada perlakuan kontrol lebih tinggi dibandingkan pada perlakuan residu pupuk N $200 \mathrm{kgha}^{-1}$. Selain itu, terjadi penurunan $\mathrm{pH}$ tanah secara signifikan pada kedua perlakuan baik pada perlakuan kontrol maupun pada perlakuan residu pupuk N $200 \mathrm{~kg} \mathrm{ha}^{-1}$ setelah panen.

Penurunan $\mathrm{pH}$ tanah pada perlakuan residu pupuk N terjadi akibat pemberian Urea secara terusmenerus pada musim tanam sebelumnya. Hal ini sejalan dengan pernyataan Utomo (2015) bahwa pada tahun ke-14 percobaan, penurunan $\mathrm{pH}$ pada perlakuan TOT dengan pemupukan $\mathrm{N}$ jangka panjang ternyata lebih tinggi dibandingkan tanpa pemupukan N. Proses nitrifikasi yang mengubah amonium yang berasal dari Urea menjadi nitrat telah menghasilkan ion $\mathrm{H}^{+}$yang dapat menurunkan $\mathrm{pH}$ tanah. Selanjutnya, penurunan $\mathrm{pH}$ tanah setelah pertanaman kacang tunggak $(\mathrm{pH}$ tanah akhir) pada perlakuan kontrol dan residu pupuk $200 \mathrm{~kg} \mathrm{~N} \mathrm{ha}{ }^{-1}$ diduga karena banyaknya kation yang diserap oleh tanaman kacang tunggak, termasuk amonium $\left(\mathrm{NH}_{4}^{+}\right)$dan banyaknya ion $\mathrm{H}^{+}$yang keluar dari akar tanaman ke larutan tanah sehingga $\mathrm{pH}$ tanah menurun.

\section{Kandungan C-organik Tanah Awal dan Akhir}

Hasil penelitian (Tabel 3) menunjukkan bahwa perlakuan residu pemupukan $\mathrm{N}$ dan sistem olah tanah serta interaksi keduanya tidak memberikan pengaruh

Tabel 3. Pengaruh residu pemupukan $\mathrm{N}$ dan sistem olah tanah terhadap C-organik tanah awal dan akhir pada tanaman kacang tunggak.

\begin{tabular}{ccc}
\hline \multirow{2}{*}{ Perlakuan } & $\begin{array}{r}\text { C-organik tanah awal } \\
(\%)\end{array}$ & $\begin{array}{c}\text { C-organik tanah akhir } \\
(\%)\end{array}$ \\
\hline N0T0 & 1,11 & 1,49 \\
N0T1 & 1,17 & 1,58 \\
N0T2 & 1,12 & 1,45 \\
N2T0 & 1,21 & 1,39 \\
N2T1 & 1,16 & 1,55 \\
N2T2 & 1,14 & 1,69 \\
\hline
\end{tabular}

Keterangan : $\mathrm{N}_{0}=$ Kontrol; $\mathrm{N}_{2}=$ Residu Pupuk N $200 \mathrm{~kg} \mathrm{ha}^{-1} ; \mathrm{T}_{0}=$ Tanpa Olah Tanah; $\mathrm{T}_{1}=$ Olah Tanah Minimum; $\mathrm{T}_{2}=$ Olah Tanah Intensif. 
nyata terhadap kandungan C-organik pada tanah awal dan akhir. Hal ini diduga karena singkatnya waktu penelitian sehingga proses dekomposisi bahan organik belum optimal. Selain itu, pada penelitian olah tanah konservasi jangka panjang tahun ke-32, kondisi tanah diduga sudah mulai mengalami pemadatan (kekerasan) sehingga aerasi tanah kurang baik. Hal ini mengakibatkan proses dekomposisi bahan organik tidak tercapai secara optimal pada olah tanah minimum dan tanpa olah tanah. Hasil penelitian saat ini sejalan dengan hasil penelitian yang dilaporkan oleh Kasno dkk. (1998), yang menunjukkan bahwa perlakuan tanpa olah tanah tidak memperlihatkan pengaruh nyata terhadap kandungan bahan organik tanah, baik pada perlakuan takaran pupuk sedang maupun takaran pupuk tinggi. Tidak berpengaruhnya perlakuan sistem olah tanah pada kandungan C-organik tanah juga sejalan dengan hasil penelitian Rosliani dkk. (2010) yang menyatakan bahwa kandungan $\mathrm{C}$-organik tanah pada perlakuan olah tanah minimum dan olah tanah intensif menunjukkan hasil yang tidak berbeda nyata.

\section{Bobot Kering Tanaman Kacang Tunggak}

Hasil penelitian (Tabel 4) menunjukkan bahwa perlakuan residu pemupukan $\mathrm{N}$ dan sistem olah tanah serta interaksi keduanya tidak memberikan pengaruh yang nyata terhadap bobot kering brangkasan, bobot kering polong dan bobot kering total tanaman kacang tunggak. Bobot kering tanaman merupakan ukuran pertumbuhan dan perkembangan tanaman karena berat kering mencerminkan akumulasi senyawa organik yang berhasil disintesis oleh tanaman. Bobot kering tanaman mencerminkan status nutrisi suatu tanaman dan juga merupakan indikator yang menentukan baik tidaknya suatu pertumbuhan dan perkembangan tanaman sehingga erat kaitannya dengan ketersediaan hara (Lubis dkk, 2015). Hal ini diduga karena rendahnya unsur hara nitrogen di dalam tanah (Tabel 1) yang mengakibatkan perlakuan residu pemupukan $200 \mathrm{~kg}$ $\mathrm{N} \mathrm{ha}^{-1}$ tidak berpengaruh nyata terhadap bobot kering tanaman kacang tunggak.

\section{Serapan N Tanaman Kacang Tunggak}

Residu pemupukan N jangka panjang serta interaksi antara sistem olah tanah dan residu pemupukan $\mathrm{N}$ tidak berpengaruh nyata terhadap serapan $\mathrm{N}$ tanaman. Hal ini diduga karena pada penelitian ini menggunakan residu pemupukan $\mathrm{N}$ dari pertanaman sebelumnya, unsur $\mathrm{N}$ yang digunakan berasal dari pemanfaatan jaringan tanaman yang telah mati. Hasil penelitian Yupitasari (2018) menunjukkan bahwa residu pemupukan Njangka panjang pada tahun ke-30, pada perlakuan tanpa pemupukan sebesar 1,3-1,5 $\mathrm{g} \mathrm{kg}^{-1}$ atau sekitar 13-15 $\mathrm{kg} \mathrm{ha}^{-1}$ dan pada perlakuan residu pemupukan N $200 \mathrm{~kg} \mathrm{ha}^{-1}$ sebesar 1,3-1,7 $\mathrm{g} \mathrm{kg}^{-1}$ atau sekitar $13-17 \mathrm{~kg} \mathrm{ha}^{-1}$. Adanya sifat $\mathrm{N}$ yang mudah tercuci dan menguap menyebabkan unsur hara ini sedikit tersedia di dalam tanah, sehingga residu N yang diserap oleh tanaman kacang tunggak hanya sedikit.

Sistem olah tanah berpengaruh sangat nyata terhadap serapan $\mathrm{N}$ brangkasan dan total serapan $\mathrm{N}$ pada tanaman kacang tunggak, namun tidak berpengaruh terhadap serapan $\mathrm{N}$ polong (Tabel 5). Tabel 5 menunjukkan bahwa serapan $\mathrm{N}$ brangkasan tanaman kacang tunggak pada perlakuan olah tanah intensif menunjukkan hasil tertinggi, namun tidak berbeda nyata dengan serapan $\mathrm{N}$ pada perlakuan olah 
tanah minimum, akan tetapi serapan $\mathrm{N}$ brangkasan pada perlakuan tanpa olah tanah menunjukkan hasil terendah. Sedangkan total serapan N pada tanaman kacang tunggak pada perlakuan olah tanah minimum menunjukkan hasil tertinggi, namun tidak berbeda nyata dengan perlakuan tanpa olah tanah, akan tetapi total serapan $\mathrm{N}$ tanaman pada perlakuan olah tanah intensif menunjukkan hasil terendah. Berdasarkan hasil penelitian Senatama (2019) tahun ke-31 menunjukkan bahwa perlakuan residu pemupukan nitrogen dan sistem olah tanah tidak mempengaruhi jumlah serapan $\mathrm{N}$ tanaman kacang hijau. Sedangkan hasil penelitian Yupitasari (2018) tahun ke-30 menunjukkan bahwa perlakuan residu pemupukan nitrogen dan sistem olah tanah masing-masing berpengaruh sangat nyata terhadap serapan $\mathrm{N}$ tanaman jagung. Namun, tidak ada pengaruh interaksi antara residu pemupukan $\mathrm{N}$ dan sistem olah tanah terhadap serapan $\mathrm{N}$ tanaman jagung. Serapan hara $\mathrm{N}$ tertinggi terdapat pada perlakuan N2T0 (residu $200 \mathrm{~kg} \mathrm{~N} \mathrm{ha}^{-1}$ dengan tanpa olah tanah), sedangkan serapan hara $\mathrm{N}$ terendah terdapat pada perlakuan NOT2 ( $0 \mathrm{~kg} \mathrm{Nha}^{-1}$ dengan olah tanah intensif).

\section{Produksi Tanaman Kacang Tunggak}

Hasil penelitian (Tabel 6) menunjukkan bahwa produksi tanaman kacang tunggak pada perlakuan residu pemupukan $\mathrm{N} 200 \mathrm{~kg} \mathrm{ha}^{-1}$ lebih tinggi dibandingkan pada perlakuan tanpa pemberian pupuk, terutama pada olah tanah minimum dan tanpa olah tanah intensif. Produksi tanaman kacang tunggak tertinggi terdapat pada perlakuan residu pemupukan $200 \mathrm{~kg} \mathrm{~N}$ $\mathrm{ha}^{-1}$ dengan olah tanah minimum, namun tidak berbeda

Tabel 4. Pengaruh residu pemupukan $\mathrm{N}$ dan sistem olah tanah terhadap bobot kering brangkasan, bobot kering polong dan bobot kering total tanaman kacang tunggak.

\begin{tabular}{cccc}
\hline Perlakuan & $\begin{array}{r}\text { Bobot kering brangkasan } \\
\left(\mathrm{kg} \mathrm{ha}^{-1}\right)\end{array}$ & $\begin{array}{r}\text { Bobot kering polong } \\
\left(\mathrm{kg} \mathrm{ha}^{-1}\right)\end{array}$ & $\begin{array}{r}\text { Bobot kering total } \\
\left(\mathrm{kg} \mathrm{ha}^{-1}\right)\end{array}$ \\
\hline N0T0 & 554,44 & 224,48 & 778,98 \\
N0T1 & 583,21 & 243,93 & 826,68 \\
N0T2 & 637,28 & 225,28 & 862,28 \\
N2T0 & 566,93 & 192,83 & 759,58 \\
N2T1 & 624,38 & 221,83 & 846,08 \\
N2T2 & 660,58 & 273,29 & 933,79 \\
\hline
\end{tabular}

Keterangan : $\mathrm{N}_{0}=$ Kontrol; $\mathrm{N}_{2}=$ Residu Pupuk N $200 \mathrm{~kg} \mathrm{ha}^{-1} ; \mathrm{T}_{0}=$ Tanpa Olah Tanah; $\mathrm{T}_{1}=$ Olah Tanah Minimum; $\mathrm{T}_{2}=$ Olah Tanah Intensif.

Tabel 5. Pengaruh sistem olah tanah terhadap serapan $\mathrm{N}$ brangkasan dan total serapan $\mathrm{N}$ pada tanaman kacang tunggak.

\begin{tabular}{ccc}
\hline Perlakuan & Serapan N brangkasan $\left(\mathrm{kg} \mathrm{ha}^{-1}\right)$ & Total serapan N tanaman $\left(\mathrm{kg} \mathrm{ha}^{-1}\right)$ \\
\hline T0 & $12,79 \mathrm{a}$ & $24,93 \mathrm{a}$ \\
T1 & $17,37 \mathrm{~b}$ & $26,14 \mathrm{a}$ \\
T2 & $17,85 \mathrm{~b}$ & $16,95 \mathrm{~b}$ \\
BNT 5\% & 3,02 & 3,10 \\
\hline
\end{tabular}

Keterangan : Angka yang diikuti oleh huruf yang sama tidak berbeda nyata menurut uji BNT 5\%. $\mathrm{N}_{0}=$ Kontrol; $\mathrm{N}_{2}=$ Residu Pupuk N $200 \mathrm{~kg} \mathrm{ha}^{-1}$. 
Tabel 6. Pengaruh residu pemupukan $\mathrm{N}$ dan sistem olah tanah terhadap produksi kacang tunggak $\left(\mathrm{mg} \mathrm{ha}^{-1}\right)$.

\begin{tabular}{cccc}
\hline \multirow{2}{*}{ Nitrogen } & \multicolumn{3}{c}{ Sistem Olah Tanah } \\
\cline { 2 - 4 } & T0 & T1 & T2 \\
\hline N0 & $1,26 \mathrm{~A}$ & $1,07 \mathrm{~B}$ & $0,74 \mathrm{~B}$ \\
& $\mathrm{a}$ & $\mathrm{b}$ & $\mathrm{c}$ \\
$\mathrm{N} 2$ & $1,26 \mathrm{~A}$ & $1,40 \mathrm{~A}$ & $1,16 \mathrm{~A}$ \\
& $\mathrm{a}$ & $\mathrm{b}$ & $\mathrm{b}$ \\
\hline BNT 5\% & & 0,14 & \\
\hline
\end{tabular}

Keterangan: Angka-angka yang diikuti huruf yang sama tidak berbeda nyata menurut uji BNT 5\%. Huruf kecil untuk baris dan huruf besar untuk kolom. T0 $=$ Tanpa Olah Tanah, $\mathrm{T} 1=$ Olah Tanah Minimum, $\mathrm{T} 2=$ Olah Tanah Intensif, $\mathrm{N} 0=$ Kontrol, N2 $=$ Residu Pemupukan $200 \mathrm{~kg} \mathrm{~N} \mathrm{ha}^{-1}$.

Tabel 7. Koefisien korelasi (r) antara serapan $\mathrm{N}$ tanaman dengan bobot kering brangkasan dan produksi kacang tunggak.

\begin{tabular}{lccc}
\hline \multicolumn{1}{c}{ Uji korelasi } & Persamaan & $\mathrm{r}$ & \\
\hline $\begin{array}{l}\text { Serapan N brangkasan }\left(\mathrm{kg} \mathrm{ha}^{-1}\right) \text { vs bobot kering brangkasan } \\
\left(\mathrm{kg} \mathrm{ha}^{-1}\right)\end{array}$ & $\mathrm{y}=19,139 \mathrm{x}+298,18$ & 0,72 & $* *$ \\
Serapan N brangkasan $\left(\mathrm{kg} \mathrm{ha}^{-1}\right)$ vs Produksi $\left(\mathrm{Mg} \mathrm{ha}^{-1}\right)$ & $\mathrm{y}=0,0385 \mathrm{x}+0,5312$ & 0,62 & $*$ \\
Residu N $\left(\mathrm{kg} \mathrm{ha}^{-1}\right)$ vs bobot kering brangkasan $\left(\mathrm{kg} \mathrm{ha}^{-1}\right)$ & $\mathrm{y}=7,4327 \mathrm{x}+595,19$ & 0,13 & tn \\
Residu N $\left(\mathrm{kg} \mathrm{ha}^{-1}\right)$ vs Produksi $\left(\mathrm{Mg} \mathrm{ha}^{-1}\right)$ & $\mathrm{y}=0,002 \mathrm{x}+1,1454$ & 0,01 & $\mathrm{tn}$ \\
\hline
\end{tabular}

Keterangan $: \mathrm{tn}=$ tidak berkorelasi nyata, $*=$ berkorelasi nyata, ${ }^{* *}=$ berkorelasi sangat nyata.

nyata dengan produksi tanaman kacang tunggak pada perlakuan $200 \mathrm{~kg} \mathrm{~N} \mathrm{ha}^{-1}$ dengan perlakuan tanpa olah tanah. Sistem olah tanah minimum mempermudah perakaran tanaman untuk berkembang dengan baik karena permukaan tanah yang diolah menyebabkan penyerapan hara dan air oleh tanaman lebih optimum. Kemudian, penggunaan residu tanaman musim sebelumnya sebagai mulsa dapat memperbaiki sifat biologi, kimia, maupun fisik tanah, sehingga dapat meningkatkan produktivitas tanah. Hal ini sesuai dengan pernyataan Utomo (2015) yang menyatakan bahwa residu tanaman dapat menekan erosi serta meningkatkan imobilisasi $\mathrm{N}$ dan ketersediaan air. Akan tetapi produksi tanaman kacang tunggak pada perlakuan residu pemupukan $\mathrm{N} 200 \mathrm{~kg} \mathrm{ha}^{-1}$ dengan olah tanah minimum yaitu sebesar $1,40 \mathrm{Mg} \mathrm{ha}^{-1}$ termasuk rendah karena menurut Koten dkk. (2013), produksi kacang tunggak dapat mencapai 2,06 - 4,70 $\mathrm{Mg} \mathrm{ha}^{-1}$. Rendahnya produksi kacang tunggak pada penelitian ini diduga karena tingginya jumlah populasi gulma pada saat tanaman memasuki fase generatif, sehingga terjadi persaingan penyerapan hara antara tanaman dengan gulma. Hal tersebut juga dapat disebabkan oleh jumlah Nyang berasal dari residu pemupukan sebelumnya masih tergolong rendah untuk memenuhi kebutuhan $\mathrm{N}$ bagi pertumbuhan dan produksi tanaman kacang tunggak.

\section{Korelasi Serapan N Tanaman dengan Bobot Kering Brangkasan dan Produksi Tanaman Kacang Tunggak}

Hasil uji korelasi pada Tabel 7 menunjukkan bahwa serapan $\mathrm{N}$ brangkasan berkorelasi positif dengan produksi tanaman kacang tunggak $\left(\mathrm{r}=0,76^{* *}\right)$. Hal ini menunjukkan bahwa produksi kacang tunggak 
meningkat sejalan dengan meningkatnya serapan $\mathrm{N}$ oleh tanaman kacang tunggak. Selanjutnya, serapan N tanaman berkorelasi nyata dengan bobot kering brangkasan $(\mathrm{r}=0,67 *)$. Hal ini diduga karena adanya peranan $\mathrm{N}$ yaitu merangsang pertumbuhan akar, batang, dan daun. Semakin tinggi serapan N tanaman maka semakin tinggi bobot kering brangkasan yang dihasilkan dan semakin tinggi pula produksi tanaman kacang tunggak yang dihasilkan. Namun, tidak terdapat korelsi antara residu $\mathrm{N}$ total tanah dengan bobot kering brangkasan dan produksi tanaman kacang tunggak. Hasil penelitian ini sejalan dengan hasil pada Tabel 1 dan 5 yang menunjukkan bahwa interaksi antara residu pemupukan $\mathrm{N}$ dan sistem olah tanah tidak berpengaruh terhadap kadar N-total tanah dan serapan $\mathrm{N}$ tanaman kacang tunggak. Hal ini diduga karena pertumbuhan tanaman kacang tunggak membutuhkan hara $\mathrm{N}$ yang tinggi, tetapi kadar residu $\mathrm{N}$ yang ada masih kurang dan tergolong rendah.

\section{KESIMPULAN}

Sistem olah tanah tidak mempengaruhi kadar $\mathrm{N}$ total tanah, namun berpengaruh sangat nyata terhadap serapan $\mathrm{N}$ brangkasan dan total serapan $\mathrm{N}$ pada tanaman kacang tunggak. Serapan N pada brangkasan tanaman kacang tunggak pada perlakuan sistem olah tanah intensif lebih tinggi dibandingkan dengan tanpa olah tanah, namun tidak tidak berbeda nyata dengan olah tanah minimum. Sedangkan total serapan $\mathrm{N}$ tanaman pada perlakuan olah tanah minimum lebih tinggi dibandingkan dengan olah tanah intensif namun tidak berbeda nyata dengan tanpa olah tanah. Residu pemupukan nitrogen tidak mempengaruhi kadar $\mathrm{N}$ total tanah dan serapan $\mathrm{N}$ pada tanaman kacang tunggak. Tidak terdapat pengaruh interaksi antara residu pemupukan nitrogen dan sistem olah tanah terhadap kadar $\mathrm{N}$ total tanah dan serapan $\mathrm{N}$, namun terdapat pengaruh interaksi terhadap produksi tanaman kacang tunggak. Produksi tanaman kacang tunggak tertinggi terdapat pada interaksi perlakuan sistem olah tanah minimum dengan residu pemupukan $200 \mathrm{~kg} \mathrm{~N}$ $\mathrm{ha}^{-1}$, namun tidak berbeda nyata dengan perlakuan tanpa olah tanah dengan kontrol dan residu pemupukan $200 \mathrm{~kg} \mathrm{~N} \mathrm{ha-1.}$

\section{UCAPAN TERIMA KASIH}

Penelitian ini merupakan bagian dari penelitian jangka panjang Prof. Muhajir Utomo tentang Pengaruh Sistem Olah Tanah dan Pemupukan N Jangka Panjang terhadap Sifat Tanah, Serapan Hara, dan Pertumbuhan Tanaman.

\section{DAFTAR PUSTAKA}

Aqil, M.dan Y.A. Rahmi. 2013. Deskripsi Varietas Unggul Jagung, Sorgum, dan Gandum. Edisi 2016. Balai Penelitian Serelia. $51 \mathrm{hlm}$.

Adisarwanto, Riwanodja, dan Suhartina. 1998. Budidaya Kacang Tunggak. MONOGRAF. BALITKABI. 1(3): 78-83.

Eviati dan Sulaeman. 2009. Analisis Kimia Tanah, Tanaman, Air dan Pupuk. Balai Penelitian Tanah. Bogor. $234 \mathrm{hlm}$.

Hanafiah, A.K. 2013. Dasar-dasar Ilmu Tanah. Rajawali Press. Jakarta. $360 \mathrm{hlm}$.

Hartatik, W. dan L. R. Widowati. 2006. Pupuk Kandang. Balai Penelitian Tanah. Bogor. 135 hlm. 
Kasno, A., J. S. Adiningsih, D. Santoso, dan D. Nursamsi. 1998. Pengelolaan Hara Terpadu untuk Meningkatkan dan Mempertahankan Produktivitas Lahan Kering Masam. Pertemuan Pembahasan dan Komunikasi Hasil Penelitian Tanah dan Agroklimat. Hlm. 161-178.

Koten, B.B., R.D. Soetrisno., N. Ngadiyono., B. Soewigno. 2013. Penampilan Produksi Hijauan Hasil Tumpangsari Arbila (Phaseolus lunatus) Berinokulum Rhizobium dan Sorgum (Sorghum bocolar) pada Jarak Tanam Arbila dan Jumlah Sorgum. J. Sains Peternakan 11 (1): 26-33.

Lubis, D.S., S.H. Asmarlaili dan M. Sembiring. 2015. Pengaruh $\mathrm{pH}$ terhadap Pembentukan Bintil Akar, Serapan Hara N, P dan Produksi Tanaman pada Beberapa Varietas Kedelai pada Tanah Inseptisol Di Rumah Kasa. Jurnal Online Agroekoteknologi. 3(3) : 1111-1115.

Rosliani, R., N. Sumarni dan I. Sulastrini. 2010. Pengaruh Cara Pengolahan Tanah dan Tanaman Kacang-Kacangan sebagai Tanaman Penutup Tanah terhadap Kesuburan Tanah dan Hasil Kubis di Dataran Tinggi. Jurnal Hortikultura. 20(1): 36-44.

Senatama, N. 2019. Pengaruh Residu Pemupukan N Jangka Panjang dan Sistem Olah Tanah terhadap Jumlah Bintil Akar, Serapan N dan Produki Tanaman Kacang Hijau ( Vigna radiata L.) di Lahan Polinela Bandar Lampung Tahun ke-31. Skripsi. Fakultas pertanian. Universitas Lampung. Bandar Lampung. 36 hlm.

Susilo, F.X. 2013. Aplikasi Stastistika untuk Analisis Data Riset Proteksi Tanaman. Anugrah Utama Raharja. Bandar Lampung. $169 \mathrm{hlm}$.

Thom, W.O. dan M. Utomo. 1991. Manajemen Laboratorium dan Metode Analisis Tanah dan Tanaman. Universitas Lampung. Bandar Lampung. $85 \mathrm{hlm}$.

Trustinah. 1998. Biologi Kacang Tunggak. Monograf BALITKABI. 3 (1): 1-19.

Utomo, M. 2012. Tanpa Olah Tanah: Teknologi Pengelolaan Pertanian Lahan Kering. Lembaga Penelitian Universitas Lampung. Bandar Lampung. $110 \mathrm{hlm}$.

Utomo, M. 2015. Tanpa Olah Tanah, Teknologi Pengelolaan Pertanian Lahan Kering. Graha Ilmu. Yogyakarta. 83-87 hlm.

Yupitasari, M. 2018. Pengaruh Pemupukan N, Residu $\mathrm{N}$ dan Tanpa Olah Tanah Jangka Panjang setelah Diolah Kembali terhadap Serapan Hara Makro dan Mikro, serta Produksi Tanaman Jagung (Zea mays L.). Tesis. Fakultas Pertanian. Universitas Lampung. Bandar Lampung. $75 \mathrm{hlm}$. 